\title{
Predisposing factors to bacterial colonization in chronic obstructive pulmonary disease
}

\author{
R. Zalacain*, V. Sobradillo*, J. Amilibia*, J. Barrón**, V. Achótegui*, J.I. Pijoan***, J.L. Llorente*
}

Predisposing factors to bacterial colonization in chronic obstructive pulmonary disease. $R$. Zalacain, V. Sobradillo, J. Amilibia, J. Barrón, V. Achótegui, J.I. Pijoan, J.L. Llorente. (C) ERS Journals Ltd 1999.

ABSTRACT: The aim of this prospective observational study was to determine those factors influencing bacterial colonization in patients with stable chronic obstructive pulmonary disease (COPD).

Eighty-eight outpatients with stable COPD and 20 patients with normal spirometry and chest radiography (controls) had a fibreoptic bronchoscopy performed with topical aerosol anaesthesia. Bacterial colonization was determined using the protected specimen brush (PSB) with a cut-off $\geq 10^{3}$ colony-forming units $\left(\mathrm{CFU} \cdot \mathrm{mL}^{-1}\right)$. The influence of age, degree of airflow obstruction, smoking habit, pack-yrs of smoking, and chest radiographic findings on bacterial colonization were assessed by univariate and multivariate analysis.

Significant bacterial growth was found in $40 \%$ of patients and in none of the controls. Haemophilus influenzae, Streptococcus viridans, S. pneumoniae and Moraxella catarrhalis were the most frequent pathogens. After adjustment for other variables, severe airflow limitation (odds ratio (OR) 5.11, 95\% confidence interval (CI) 1.45-17.9) and current smoking (OR 3.17, 95\% CI 2.5-8) remained associated with positive bacterial cultures. When only potentially pathogenic micro-organisms were considered, significant bacterial growth was found in $30.7 \%$ of patients, with severe airflow obstruction (OR 9.28, 95\% CI 2.19-39.3) being the only variable independently associated with positive bacterial cultures.

Our results show that stable chronic obstructive pulmonary disease patients have a high prevalence of bacterial colonization of distal airways which is mainly related to the degree of airflow obstruction and cigarette smoking.

Eur Respir J 1999; 13: 343-348.

\author{
Services of *Pneumology and **Micro- \\ biology and the ***Unit of Clinical \\ Epidemiology, Hospital de Cruces, \\ Cruces-Barakaldo, Vizcaya, Spain.
}

Correspondence: R. Zalacain

Servicio de Neumologá

Hospital de Cruces

Plaza de Cruces s/n

E-48903 Barakaldo

Vizcaya

Spain Fax: 34946006541

Keywords: Airflow obstruction bacterial colonization

chronic obstructive pulmonary disease protected specimen brush smoking

Received: December 21997 Accepted after revision July 131998
Despite intensive investigation, the precise role of bacterial infection in the production and recurrent aspects of chronic obstructive pulmonary disease (COPD) has yet to be elucidated $[1,2]$. It has been estimated that the lower respiratory tract of stable COPD patients is colonized in $50-100 \%$ of cases $[3,4]$. In most studies, however, the tracheobronchial microflora was characterized by unreliable diagnostic techniques (e.g. expectorated sputum, transtracheal aspiration) owing to the lack of specificity and the absence of quantitative cultures [5-8]. Fibreoptic bronchoscopy using a protected specimen brush (PSB) catheter is a highly sensitive and specific technique used to obtain uncontaminated specimens for culture from the lower respiratory tract [9]. In patients with stable COPD, the prevalence of lower airway bacterial colonization using the PSB varies between 25 and 55.5\% [10-12]. However, predisposing factors to bacterial colonization in patients with stable COPD have not been well defined.

To determine precisely the influence of different factors, such as age, degree of airflow obstruction, smoking habit, pack-yrs of smoking and chest radiographic find-

For editorial comments see page 233 ings, on the detection of bacteria in COPD patients, a prospective study was conducted using the PSB and quantitative cultures.

\section{Materials and methods}

\section{Study population}

The study was carried out in a 1,000-bed teaching hospital in Bizkaia, Basque Country (Spain) between January 1, 1994 and December 31, 1995. A total of 1,002 patients had been explored by fibreoptic bronchoscopy in 1995, 373 of whom had undergone this procedure on an outpatient basis. Eighty-eight outpatients who fulfilled clinical criteria of chronic bronchitis and evidence of airflow obstruction (forced expiratory volume in one second (FEV1) $<80 \%$ of the predicted value and FEV1/forced vital capacity (FVC) $<70 \%$, with an increase of $<10 \%$ in FEV1 after inhalation of a $\beta$-agonist aerosol) [13] were enrolled into the study. All patients had serial lung function studies compatible with the diagnosis of COPD. The patients had stable respiratory symptoms [14], all expectorated mucoid sputum, were afebrile and had not taken any antibiotics within the previous 30 days or corticosteroids within the 
previous 3 months. None of the patients had been admitted to any hospital during the previous 6 months. Patients with bronchiectasis or a past history of haemoptysis were excluded. Bronchiectasis was excluded according to the absence of suggestive clinical and radiological data. Five patients with doubtful images on chest radiography had computed tomographic (CT) scans of the thorax to confirm the absence of bronchiectasis. Patients with bronchoscopically visible structural endobronchial disease, neoplastic infiltration, residual stenosis or purulent or mucopurulent secretions in the respiratory tract were also excluded. All patients had a good nutritional status (no signs of starvation or recent weight loss), the respiratory disease was the main disorder and none of them had other concurrent conditions that could have altered the bacterial flora. Two patients with mucopurulent secretions in the respiratory tract at the time of bronchoscopy were excluded, given that in COPD patients this type of secretion is usually associated with respiratory infection [14].

The study was explained fully to each patient and written informed consent was obtained from all participants. Of the 88 outpatients with stable COPD, 34 were referred for fibreoptic bronchoscopy because of an abnormal chest radiograph (pulmonary nodule in 18 , mass lesion in nine, laminar atelectasis in three, fibrous lesion in two and pleural image in two patients). The remaining 54 patients, who have been followed in the outpatient clinic of the service of pneumology for a long time, with a normal chest radiograph and no clinical indication requiring fibreoptic bronchoscopy, accepted microbiological sampling with the PSB. The control group consisted of 20 asymptomatic patients with a tentative diagnosis of sleep apnoea syndrome who, at the time of the study, underwent dynamic pharyngoscopy with the fibreoptic bronchoscope and gave their consent for sampling with the PSB. The study protocol was approved by the ethical committee of the authors' institution.

A questionnaire was used to obtain information on smoking habits at the time of examination (smokers, nonsmokers, exsmokers, time elapsed from cessation of smoking and tobacco consumption, expressed as pack-yrs). Nonsmokers were defined as those patients who had never smoked cigarettes or had smoked less than one cigarette a day for $1 \mathrm{yr}$, or less than 20 packs of cigarettes in a lifetime. Current smokers were those who were smoking regularly on a daily basis at least within 1 month before examination. Forced spirometry with bronchodilator therapy was performed in all patients before inclusion in the study [13]. The degree of airflow obstruction was considered severe when FEV 1 was $<50 \%$ pred, moderate when FEV 1 was $50-64 \%$ pred and mild when FEV1 was $65-79 \%$ pred [ 15 ]. Chest radiographs were obtained at least $48 \mathrm{~h}$ before microbiological sampling.

\section{Microbiological sampling}

Before initiating the procedure, topical anaesthesia was achieved by aerosolization of $10 \mathrm{~mL}$ of $5 \%$ lidocaine through a mouthpiece over a $15 \mathrm{~min}$ period. No other type of anaesthetic was used. No topical anaesthetics were injected through the bronchoscope channel and no suction was applied before obtaining the specimen. A PSB catheter (Mill-Rose Laboratories, Mentor, OH, USA) was inserted through the inner suction channel of a fibreoptic bron- choscope (Machida FBS-6TL II) and advanced, under direct vision, to obtain segmental airways secretion from the lower right or left lobe (i.e. opposite the site of the radiographic abnormality) according to the technique of WIMBERLEY et al. [9]. The brush was aseptically cut into a vial containing $1.0 \mathrm{~mL}$ sterile Ringer's lactate solution and delivered to the laboratory in $<10 \mathrm{~min}$.

\section{Microbiological processing}

The vial was vigorously agitated on a vortex mixer to suspend thoroughly all material from the brush. The PSB effluents were cultured quantitatively by plating $0.1 \mathrm{~mL}$ and $0.01 \mathrm{~mL}$ of the original specimens on blood agar and chocolate agar (aerobic pathogens), Schaelder medium (anaerobic pathogens), buffered charcoal-yeast extract medium (Legionella pneumophila) and Sabouraud medium at $22^{\circ}$ and $37^{\circ} \mathrm{C}$ (fungi). Samples were also cytocentrifuged, Gram-stained and examined under light microscopy for the identification of squamous epithelial cells. Recovery of squamous epithelial cells was considered an accurate predictor of oropharyngeal contamination, i.e. unsatisfactory specimens. For this reason, four samples were discarded. Accepted laboratory methods were used for bacterial identification and susceptibility testing [16]. Only quantitative cultures with a concentration of $\geq 10^{3}$ colony-forming units $(\mathrm{CFU}) \cdot \mathrm{mL}^{-1}$ of bacterial pathogens were considered positive $[9,17]$. Bacterial counts $<10^{3} \mathrm{CFU} \cdot \mathrm{mL}^{-1}$ were considered negative. A separate analysis including only potentially pathogenic micro-organisms (PPM), i.e. those recognized as causative pathogens of respiratory tract infections (Haemophilus influenzae, Streptococcus pneumoniae, Moraxella catarrhalis, and others) and excluding non-PPM (Streptococcus viridans, Neisseria spp. and others) [10] was carried out. Samples from expectorated sputum were not cultured.

\section{Statistical analysis}

Results are expressed as means $\pm \mathrm{SD}$ and range for quantitative variables, and as relative frequencies and, in some cases, 95\% confidence intervals (CI) for categorical variables. Data were compared using a Chi-squared test or Fisher's exact test when necessary. The Chi-squared test for trend was applied for dose-response analysis and the Student's t-test for independent samples was used for betweengroup comparisons of quantitative variables. Statistical significance was set at $\mathrm{p}<0.05$. In order to determine the predictive value of five variables (age, degree of airflow obstruction, smoking habit, pack-yrs of smoking and chest radiographic findings) on bacterial colonization of the lower airways, logistic regression models with assessment of first-order interactions were estimated. The SYSTAT 5.02 and EPIINFO 6 computer programs were used for statistical analysis.

\section{Results}

The general characteristics of COPD patients and controls are shown in table 1. Patients in the control group were younger than persons with COPD (mean age 61.5 versus $66.1 \mathrm{yrs}, \mathrm{p}=0.024$ ) and had normal lung function and no abnormalities on chest radiography. Only two 
Table 1. - Baseline characteristics of patients with chronic obstructive pulmonary disease (COPD) and controls

\begin{tabular}{|c|c|c|c|}
\hline Variable & $\begin{array}{l}\text { COPD patients } \\
\quad(\mathrm{n}=88)\end{array}$ & $\begin{array}{l}\text { Controls } \\
(\mathrm{n}=20)\end{array}$ & $\mathrm{p}$-value \\
\hline Age yrs* & $66.1 \pm 7.2$ & $61.5 \pm 8.1$ & 0.024 \\
\hline Sex male/female & $88 / 0$ & $20 / 0$ & \\
\hline \multicolumn{4}{|l|}{ Spirometric data* } \\
\hline FVC L & $2.94 \pm 0.6$ & $3.78 \pm 0.7$ & $<0.01$ \\
\hline FVC \% & $70.6 \pm 13.1$ & $88.9 \pm 9.9$ & $<0.01$ \\
\hline FEV1 L & $1.68 \pm 0.4$ & $2.89 \pm 0.5$ & $<0.01$ \\
\hline FEV1 \% & $55.7 \pm 12.9$ & $88.4 \pm 8.2$ & $<0.01$ \\
\hline FEV1/FVC \% & $55.3 \pm 9$ & $77.8 \pm 7.2$ & $<0.01$ \\
\hline \multicolumn{4}{|l|}{ Smoking habit ${ }^{+}$} \\
\hline Smokers & $38(43.2)$ & $2(10)$ & \\
\hline Exsmokers & $50(56.8)$ & $16(80)$ & \\
\hline Nonsmokers & & $2(10)$ & \\
\hline \multicolumn{4}{|l|}{ Pack-yrs* } \\
\hline Smokers & $54.5 \pm 11.4$ & $38.5 \pm 3.5$ & 0.020 \\
\hline Exsmokers & $52.9 \pm 17.2$ & $29.6 \pm 9.6$ & $<0.01$ \\
\hline
\end{tabular}

*: Data are mean $\pm \mathrm{SD} ;{ }^{+}$: data are numbers with percentages in parenthesis. FVC: forced vital capacity; FEV1: forced expiratory volume in one second.

patients were current smokers. In the study group, airway obstruction was severe in 26 patients, moderate in 36 and mild in 26. A bronchodilator response was not observed in 42 patients and the remaining 46 patients had a mean increase in FEV1 of $5.8 \pm 2 \%$. Fifty patients were exsmokers and 38 active smokers. The mean time elapsed since cessation of smoking was 10.1 yrs (range 1-40 yrs). No statistically significant differences in pack-yrs of smoking between smokers and exsmokers were found. Of the 34 patients with abnormal chest radiography, the final diagnosis was a malignant tumour in 19 and a benign process in 15. The baseline characteristics of the 19 lung cancer patients were not significantly different from those of the remaining 69 COPD patients. All patients with neoplasm had a Karnovsky index between 90 and $100 \%$.

The PSB demonstrated significant $\left(\geq 10^{3} \mathrm{CFU} \cdot \mathrm{mL}^{-1}\right)$ bacterial growth in $36(40.9 \%)$ COPD patients (table 2$)$. A total of 45 micro-organisms were isolated, with $H$. influenzae (31.4\%), S. viridans (24.4\%) and S. pneumoniae $(15.5 \%)$ being the most common. Only three Gram-negative Enterobacteriaceae were isolated (two Escherichia coli and one Serratia marcescens). Bacterial counts $\geq 10^{4}$ $\mathrm{CFU} \cdot \mathrm{mL}^{-1}$ were recovered for eight organisms (five $H$. influenzae, one $S$. pneumoniae, one $M$. catarrhalis and one $S$. marcescens). If only PPM were considered, PSB sampling was positive in $27(30.7 \%)$, with a total of 29 organisms isolated. Considering a lower colony count $\left(\geq 10^{2} \mathrm{CFU} \cdot \mathrm{mL}^{-1}\right)$, bacterial growth was obtained in 46 $(52.3 \%)$ of cases and in $31(35.2 \%)$ if only PPM were taken into account. In 12 patients, PSB isolates yielded $<10^{3}$ $\mathrm{CFU} \cdot \mathrm{mL}^{-1}$ (table 3 ). Cultures of all PSB specimens obtained in controls showed no growth except for $2 \times 10^{2}$ $\mathrm{CFU} \cdot \mathrm{mL}^{-1}$ of $S$. viridans in a 57 -yr-old current smoker.

Bacterial growth $\left(\geq 10^{3} \mathrm{CFU} \cdot \mathrm{mL}^{-1}\right)$ was significantly more frequent in patients with severe airflow obstruction $(15 / 26,57.7 \%)$ than in patients with moderate $(15 / 36$, $41.7 \%)$ or mild $(6 / 26,23.1 \%)$ functional impairment $(\mathrm{p}=$ $0.04)$. There was a statistically significant $(\mathrm{p}=0.011)$ linear trend between the increase in airflow obstruction and the number of positive bacterial cultures. Patients with less severe lung function abnormalities had less severe bacteriology with a lower number of PPM than patients with more advanced lung disease (table 4). The prevalence of positive bacterial cultures was significantly higher in current smokers than in exsmokers $(55.3 \%$ versus $30 \%$, $\mathrm{p}=0.017)$. However, no differences in the prevalence of positive cultures in relation to pack-yrs of smoking were found. Positive microbiological results were found in $42.6 \%(23 / 54)$ of patients with normal chest radiography and in $38.2 \%(13 / 34)$ of patients with abnormal chest radiography $(\mathrm{p}=\mathrm{NS})$. In the group of patients with abnormal chest radiography, PSB sampling was positive in $33.3 \%(5 / 15)$ of those with benign lesions and in $42 \%(8 /$ 19) of those with lung tumour ( $\mathrm{p}=\mathrm{NS})$.

After multivariate analysis, airflow obstruction and smoking habit were independent predictors of positive bacterial cultures $\left(\geq 10^{3} \mathrm{CFU} \cdot \mathrm{mL}^{-1}\right)$ on PSB sampling. The likelihood of obtaining positive results was significantly higher in stable COPD patients with severe airflow obstruction than in stable COPD patients with mild obstruction (odds ratio (OR) 5.11, 95\% CI 1.45-17.9; $\mathrm{p}=0.011$ ) and higher in smokers than in nonsmokers (OR 3.17, 95\% CI 2.5-8; $\mathrm{p}=0.015$ ). Patients with moderate airflow obstruction also showed a higher probability of bacterial counts $\geq 10^{3}$ CFU. $\mathrm{mL}^{-1}$ than patients with mild airflow obstruction (OR $2.47,95 \%$ CI $0.76-7.95 ; p=0.129$ ), although the difference was not statistically significant.

In the subset of patients with PPM, bacterial growth was significantly more frequent in those with severe obstruction $(53.8 \%, 14 / 26)$ than in those with moderate $(27.8 \%$, $10 / 36)$ or mild $(11.5 \%, 3 / 26)$ airflow obstruction $(\mathrm{p}=$ $0.004)$. There was also a statistically significant linear trend $(\mathrm{p}=0.001)$ between the increase in airflow obstruction and the number of positive bacterial cultures. The prevalence of positive microbiological results was not significantly different between smokers and exsmokers (36.8 versus $26 \%$ ) or in relation to pack-yrs of smoking or radiological findings. After multivariate analysis, airflow obstruction was the only independent predictor of positive PPM culture $\left(\geq 10^{3} \mathrm{CFU} \cdot \mathrm{mL}^{-1}\right)$ on PSB sampling. The likelihood of obtaining positive results was significantly higher in stable COPD patients with severe airflow obstruction than in patients with mild obstruction (OR 9.28, 95\% CI 2.19-39.3; $\mathrm{p}=0.002)$. Patients with moderate 
Table 2. - Protected specimen brush culture $\left(\geq 10^{3}\right.$ colony forming units (CFU) $\mathrm{mL}^{-1}$ ) in 36 patients with stable chronic obstructive pulmonary disease

\begin{tabular}{|c|c|c|}
\hline $\begin{array}{l}\text { Case } \\
\text { no. }\end{array}$ & Bacteria & $\mathrm{CFU} \cdot \mathrm{mL}^{-1}$ \\
\hline 1 & Streptococcus pneumoniae & $\geq 1000$ \\
\hline 2 & Haemophilus influenzae & $\geq 1000$ \\
\hline 3 & Streptococcus viridans & $\geq 1000$ \\
\hline 4 & S. pneumoniae & $\geq 10,000$ \\
\hline \multirow[t]{2}{*}{5} & H. influenzae & $\geq 10,000$ \\
\hline & Serratia marcescens & $\geq 10,000$ \\
\hline \multirow[t]{2}{*}{6} & Escherichia coli & $\geq 1000$ \\
\hline & S. viridans & $\geq 1000$ \\
\hline 7 & H. influenzae & $\geq 1000$ \\
\hline 8 & H. influenzae & $\geq 10,000$ \\
\hline 9 & H. influenzae & $\geq 1000$ \\
\hline 10 & H. influenzae & $\geq 10,000$ \\
\hline 11 & S. pneumoniae & $\geq 1000$ \\
\hline \multirow[t]{2}{*}{12} & S. viridans & $\geq 1000$ \\
\hline & Coagulase-negative staphylococcus & $>1000$ \\
\hline 13 & H. influenzae & $\geq 1000$ \\
\hline \multirow[t]{2}{*}{14} & S. viridans & $\geq 1000$ \\
\hline & Coagulase-negative staphylococcus & $\geq 1000$ \\
\hline 15 & Moraxella catarrhalis & $\geq 1000$ \\
\hline 16 & H. influenzae & $>1000$ \\
\hline 17 & M. catarrhalis & $\geq 10,000$ \\
\hline 18 & H. influenzae & $\geq 10,000$ \\
\hline \multirow[t]{2}{*}{19} & S. pneumoniae & $\geq 1000$ \\
\hline & Staphylococcus aureus & $\geq 1000$ \\
\hline \multirow[t]{2}{*}{20} & S. pneumoniae & $\geq 1000$ \\
\hline & S. viridans & $\geq 1000$ \\
\hline 21 & H. influenzae & $\geq 1000$ \\
\hline 22 & E. coli & $\geq 1000$ \\
\hline 23 & H. influenzae & $\geq 1000$ \\
\hline 24 & M. catarrhalis & $\geq 1000$ \\
\hline 25 & H. influenzae & $\geq 1000$ \\
\hline \multirow[t]{2}{*}{26} & S. viridans & $\geq 1000$ \\
\hline & Prevotella melaninogenicus & $\geq 1000$ \\
\hline 27 & H. influenzae & $\geq 10,000$ \\
\hline 28 & S. viridans & $\geq 1000$ \\
\hline \multirow[t]{2}{*}{29} & H. influenzae & $\geq 1000$ \\
\hline & S. viridans & $\geq 1000$ \\
\hline \multirow[t]{2}{*}{30} & S. viridans & $\geq 1000$ \\
\hline & Peptostreptococcus anaerobius & $\geq 1000$ \\
\hline 31 & M. catarrhalis & $\geq 1000$ \\
\hline 32 & S. pneumoniae & $\geq 1000$ \\
\hline 33 & S. viridans & $\geq 1000$ \\
\hline 34 & S. pneumoniae & $\geq 1000$ \\
\hline 35 & S. viridans & $\geq 1000$ \\
\hline 36 & Streptococcus sanguis II & $\geq 1000$ \\
\hline
\end{tabular}

airflow obstruction also showed a trend towards a higher probability of bacterial counts $\geq 10^{3} \mathrm{CFU} \cdot \mathrm{mL}^{-1}$ than patients with mild airflow obstruction (OR 2.95, 95\% CI $0.71-12.1 ; \mathrm{p}=0.134)$.

\section{Discussion}

Using a highly reliable sampling technique, the PSB, this study showed significant bacterial growth in the lower airways in $40.9 \%$ of patients with stable COPD and that bacterial colonization was influenced by the degree of airflow obstruction and current smoking. When the subgroup of patients with PPM was considered, PSB sampling was positive in $30.7 \%$ of cases, with the degree of airflow
Table 3. - Protected specimen brush culture $\left(<10^{3}\right.$ colony forming units (CFU) $\cdot \mathrm{mL}^{-1}$ ) in 12 patients with stable chronic obstructive pulmonary disease

\begin{tabular}{clr}
\hline $\begin{array}{l}\text { Case } \\
\text { no. }\end{array}$ & Bacteria & CFU· $\mathrm{mL}^{-1}$ \\
\hline 1 & & \\
2 & Streptococcus viridans & $<1000$ \\
3 & Escherichia coli & $<100$ \\
4 & Moraxella catarrhalis & $<1000$ \\
5 & Streptococcus pneumoniae & $<1000$ \\
6 & Neisseria spp. & $<1000$ \\
& Haemophilus influenzae & $<1000$ \\
7 & Pseudomonas aeruginosa & $<1000$ \\
8 & H. influenzae & $<1000$ \\
& S. viridans & $<100$ \\
9 & Neisseria spp. & $<100$ \\
10 & S. viridans & $<1000$ \\
& S. viridans & $<1000$ \\
11 & Neisseria meningitidis & $<1000$ \\
& S. viridans & $<1000$ \\
12 & Neisseria spp. & $<1000$ \\
& S. viridans & $<100$ \\
\hline
\end{tabular}

obstruction being the only variable predictive of positive microbiological results. CABELLO et al. [10] using a cut-off point of $\geq 10^{2} \mathrm{CFU} \cdot \mathrm{mL}^{-1}$, recently reported bacterial colonization in $83 \%$ of clinically stable COPD patients and in $47 \%$ of long-term tracheostomized patients.

It is well known that the lower airways of healthy individuals are not colonized by bacteria [18], whereas patients with COPD are frequently infected by bacteria [3, 4], possibly because of impairment of the mucociliary system [19]. However, several aspects of the problem, such the percentage of COPD patients with significant bacterial colonization, the spectrum of pathogens colonizing the lower respiratory tract [20] and predisposing factors to bacterial colonization, are unclear.

Much of the conflict in the data has been due to the heterogeneity of patients studied and to the characterization of the tracheobronchial microflora by expectorated sputum $[6,7]$ or transtracheal aspiration $[7,8]$, with its inherent pitfalls. Cultures of sputum specimens in COPD patients are unreliable because of contamination by the oropharyngeal flora and, therefore, were not employed. Fibreoptic bronchoscopy using the PSB is a highly reliable technique by which to obtain uncontaminated specimens for culture from the lower respiratory tract. Although PSB sampling is a common and standard procedure, it may be argued that a single negative PSB sample is considered representative of the bacterial environment of the whole two lungs, assuming that PSB samples taken at the same time from other parts of the lungs would also be sterile. This has been accepted by other authors $[10,12]$ and no previous studies addressing the reproducibility of results of PSB sampling between specimens and in different parts of the lung have been published. A standard criterion for colonization of the lower airways has not yet been defined and, although a cut-off point of $\geq 10^{2} \mathrm{CFU} \cdot \mathrm{mL}^{-1}$ was used in a recent report [10], the $\geq 10^{3} \mathrm{CFU} \cdot \mathrm{mL}^{-1}$ criterion was adopted here as the cut-off point as commonly used in other studies $[11,12,21]$. The present study investigated a homogeneous group of patients with stable COPD in clinical terms (no increased dyspnoea, sputum production or 
Table 4. - Distribution of 45 micro-organisms isolated according to degree of airflow obstruction

\begin{tabular}{lccc}
\hline & \multicolumn{3}{c}{$\begin{array}{c}\text { Degree of } \\
\text { airflow obstruction }\end{array}$} \\
\cline { 2 - 4 } Bacterium & 8 & 8 & \\
\hline Severe & Moderate Mild \\
Streptococcus viridans & 2 & 5 & 4 \\
Streptococcus pneumoniae & 3 & 3 & 1 \\
Moxarella catarrhalis & 1 & 3 & \\
Escherichia coli & 2 & & \\
Coagulase-negative staphylococcus & & 2 & \\
Staphylococcus aureus & 1 & & \\
Serratia marcescens & 1 & & \\
Streptococcus sanguis & & 1 & \\
Peptostreptococcus anaerobius & 1 & & 5 \\
Prevotella melaninogenicus & & & \\
PPM & 16 & 10 & 3 \\
Non-PPM & 3 & 8 & 5 \\
\hline
\end{tabular}

PPM: potentially pathogenic micro-organisms.

sputum purulence) who had not been admitted to hospital recently or treated with antibiotics or corticosteroids. The selection criterion of no hospital admissions in the last 6 months was established to prevent the potential presence of nosocomial flora. This could suggest that patients did not have severe COPD, but there were 26 patients with FEV1 $<50 \%$ (13 of them with FEV1 $<40 \%$ ). Furthermore, a 30day period without antimicrobials is a sufficient interval to minimize the antibiotic therapy-related effect on yield. In relation to the number of COPD exacerbations in the last 12 months, no reliable information could be provided because not all patients had visited the hospital at the time of an exacerbation (some were attended by family phy-sicians and some were self-medicated). For this reason, this variable was not evaluated. Topical anaesthesia with aerosol was used exclusively in an attempt to prevent tracheobronchial contamination by the upper airway bacterial flora, as may occur when a solution of an anaesthetic agent is used. Specimens containing squamous epithelial cells were considered unsatisfactory and discarded.

In contrast to sterile PSB cultures obtained in controls, significant bacterial colonization was found in $40.9 \%$ of patients with stable COPD. PSB cultures resulted in $\geq 10^{3}$ $\mathrm{CFU} \cdot \mathrm{mL}^{-1}$ in $55.5 \%(10 / 18)$ of the patients reported by CABELlo et al. [10] and in 33.3\% (6/18) of those reported by VEREEN et al. [11]. Monsó et al. [12], using a similar protocol to that of the present study, obtained positive PSB cultures mainly for $H$. influenzae and $S$. pneumoniae, in 10 of $40(25 \%)$ stable COPD outpatients. In the present study, the most frequently cultured pathogens were $H$. influenzae, $S$. viridans, $S$. pneumoniae and $M$. catarrhalis. With the exception of $S$. viridans [22], these pathogens account for $85-95 \%$ of all bacterial exacerbations of chronic bronchitis $[6,21]$. S. viridans has been isolated during exacerbations $[23,24]$ and, although it cannot be stated that this was the cause, $S$. viridans has been implicated as a causative organism of pneumonia in patients with COPD $[25,26]$.

Airflow obstruction and smoking habit were the only two independent predictors of lower respiratory tract colonization in the multivariate analysis. By contrast, when only PPM was taken into account, the degree of airflow obstruction was the single predictor in the multivariate analysis. The ageing process is associated with multiple deficits in pulmonary immune function and host defence mechanisms [27]. In this study, however, age did not seem to predispose stable COPD patients to significant bacterial colonization. This was further supported by the finding of sterile cultures in controls. Although the patients in the control group were somewhat younger than the patients with COPD, five of them were $>65$ yrs of age. The relationship with comorbidity as a colonization risk factor was not examined in this study, since the patients did not have other concurrent conditions; however, abnormal findings on chest radiography did not influence the results either. It has been shown that PSB cultures are of limited value in structural endobronchial disease, which leads to colonization with large quantities of bacteria in approximately half of the cases [28]. For this reason, bronchoscopically visible structural endobronchial disease and neoplastic infiltration were considered to be exclusion criteria in the present study. It should be noted that patients with malignant tumours had a Karnovsky performance index between 90 and $100 \%$ when quantitative cultures of PSB specimens were obtained, so that impairment of normal host defence mechanisms would presumably have had little influence on the results.

The degree of airflow limitation was a major predisposing factor to bacterial colonization of the lower respiratory tract in stable COPD patients. The more severe the airflow obstruction, the greater the likelihood of obtaining positive PSB cultures. To the authors' knowledge, this finding has not been reported previously. In patients with a higher degree of airflow obstruction, a greater impairment of the mucociliary clearance system may be expected [29], thus facilitating local bacterial colonization. The wellknown deleterious effect of heavy smoking on the lower respiratory tract clearance mechanisms $[30,31]$ and the role of cigarette smoking as a risk factor for airway colonization were also confirmed by the present findings. The recognized beneficial effect of smoking cessation on pulmonary function and hypersecretion of mucus [31-33] was apparent by a significantly lower prevalence of positive bacterial cultures in exsmokers than in current smokers, although this difference disappeared when the subgroup of patients with PPM was analysed separately. The results, however, were not influenced by pack-yrs of smoking, indicating that bacterial colonization in COPD patients is more closely associated with the effects of current smoking than with pack-yrs of smoking.

In conclusion, patients with stable chronic obstructive pulmonary disease have a high prevalence of bacterial colonization of distal airways, which is mainly related to the degree of airflow obstruction and cigarette smoking. According to data in this study, however, the role of bacterial pathogens in chronic obstructive pulmonary disease cannot be ascertained. Patients with significant bacterial colonization in the protected specimen brush sample were completely asymptomatic from a clinical point of view, so it is difficult to define the role played by these micro-organisms in the development and recurrent aspects of chronic obstructive pulmonary disease.

Acknowledgement. The authors thank M. Pulido for editing the manuscript and editorial assistance. 


\section{References}

1. Murphy TF, Sethi S. Bacterial infection in chronic obstructive pulmonary disease. Am Rev Respir Dis 1992; 146: 1067-1083.

2. Tager I, Speizer FE. Role of infection in chronic bronchitis. $N$ Engl J Med 1975; 292: 563-571.

3. Elborn JS, Shale DJ. Infection of the airways. Curr Opin Infect Dis 1992; 5: 170-175.

4. Palmer LB. Bacterial colonization: pathogenesis and clinical significance. Clin Chest Med 1987; 8: 455-466.

5. Gross NJ. Chronic obstructive pulmonary disease. Current concepts and therapeutic approaches. Chest 1990; 97: Suppl. 2, 19S-23S.

6. Ball P. Epidemiology and treatment of chronic bronchitis and exacerbations. Chest 1995; 108: Suppl. 2, 43S-52S.

7. Irwin RS, Arickson AD, Pratter MR, et al. Prediction of tracheobronchial colonization in current cigarette smokers with chronic bronchitis. J Infect Dis 1982; 145: 234 241.

8. Bjerkestrand M, Digranes A, Schreiner A. Bacteriological findings in transtracheal aspirates from patients with chronic bronchitis and bronchiectasis. Scand J Respir Dis 1975; 56: 201-207.

9. Wimberley NW, Bass JB Jr, Boyd BW, et al. Use of a bronchoscopic protected catheter brush for the diagnosis of pulmonary infections. Chest 1982; 81: 556-562.

10. Cabello H, Torres A, Celis R, et al. Bacterial colonization of distal airways in healthy subjects and chronic lung disease: a bronchoscopic study. Eur Respir J 1997; 10: 1137-1144.

11. Vereen L, Smart LM, George RB. Antibody coating and quantitative cultures of bacteria in sputum and bronchial brush specimens from patients with stable bronchitis. Chest 1986; 90: 534-536.

12. Monsó E, Ruiz J, Rosell A, et al. Bacterial infection in chronic obstructive pulmonary disease. A study of stable and exacerbated outpatients using the protected specimen brush. Am J Respir Crit Care Med 1995; 152: 1316-1320.

13. American Thoracic Society. Standards for the diagnosis and care of patients with chronic obstructive pulmonary disease. Am J Respir Crit Care Med 1995; 152: S77-S120.

14. Anthoniesen NR, Manfreda J, Warren CPW, et al. Antibiotic therapy in exacerbations of chronic obstructive pulmonary disease. Ann Intern Med 1987; 106: 196-204.

15. Snider GL, Kory RC, Lyons HA. Grading pulmonary function impairment by means of pulmonary function tests. Dis Chest 1967; 52: 270-271.

16. Murray PR, Baron EJ, Pfaller MA, et al. Manual of Clinical Microbiology, 6th Edn. Washington, DC, American Society of Microbiology, 1995.

17. Baselki VS, Wunderink RG. Bronchoscopic diagnosis of pneumonia. Clin Microbiol Rev 1994; 7: 533-558.

18. Van Alphen L, Jansen HM, Dankert J. Virulence factors in the colonization and persistence of bacteria in the airways. Am J Respir Crit Care Med 1995; 151: 2094-2100.

19. Wilson R, Dowling RB, Jackson AD. The biology of bacterial colonization and invasion of the respiratory mucosa. Eur Respir J 1996; 9: 1523-1530.

20. Sachs FL. Chronic bronchitis. In: Pennington JE, ed. Respiratory Infections: Diagnosis and Management. 2nd Edn. New York, Raven Press, 1988, pp. 142-158.

21. Nicotra MB, Rivera W, Awe RJ. Antibiotic therapy of acute exacerbations of chronic bronchitis. A controlled study using tetracycline. Ann Intern Med 1982; 97: 1821.

22. Harlid R, Anderson G, Frostell CG, et al. Respiratory tract colonization and infection in patients with chronic tracheostomy. A one-year study in patients living at home. Am J Respir Crit Care Med 1996; 154: 124-129.

23. Fagon JY, Chastre J, Trouillet JL, et al. Characterization of distal bronchial microflora during acute exacerbation of chronic bronchitis. Am Rev Respir Dis 1990; 142: 1004-1008.

24. Irwin RS, Corrao WM, Erickson AD, et al. Characterization by transtracheal aspiration of the tracheobronchial microflora during acute exacerbations of chronic obstructive bronchitis. Am Rev Respir Dis 1980; 121: Suppl., 150 (Abstract).

25. Marrie TJ, Durant H, Yates L. Community-acquired pneumonia requiring hospitalization: 5 -year prospective study. Rev Infect Dis 1989; 11: 586-599.

26. Torres A, Dorca J, Zalacain R, et al. Community-acquired pneumonia in chronic obstructive pulmonary disease. A Spanish multicenter study. Am J Respir Crit Care Med 1996; 154: 1456-1461.

27. Gyetko MR, Toews GB. Immunology of the aging lung. Clin Chest Med 1993; 14: 379-391.

28. Pollock HM, Hawkins EL, Bonner JR, et al. Diagnosis of bacterial pulmonary infections with quantitative protected catheter cultures obtained during bronchoscopy. J Clin Microbiol 1983; 17: 255-259.

29. Jansen HM, Sachs AEP, Van Alphen L. Predisposing conditions to bacterial infections in chronic obstructive pulmonary disease. Am J Respir Crit Care Med 1995; 151: 2073-2080.

30. Doll R, Peto R. Mortality in relation to smoking: 20 years' observations on male British doctors. BMJ 1976; 2: 1525-1536.

31. Fletcher C, Peto R. The natural history of chronic airflow obstruction. BMJ 1977; 1: 1645-1648.

32. Sherrill DL, Holberg CJ, Enright PL, et al. Longitudinal analysis of the effects of smoking onset and cessation on pulmonary function. Am J Respir Crit Care Med 1994; 149: 591-597.

33. Sherrill DL, Lebowitz MD, Burrows B. Epidemiology of chronic obstructive pulmonary disease. Clin Chest Med 1990; 11: 375-387. 